\title{
Design and Synthesis of an Activity Probe for Protein Tyrosine Phosphatases
}

\author{
Lee-Chiang Lo*（羅禮強 ), Hsin-Yi Wang（王欣一）and Zi-Jien Wang（王子健） \\ Department of Chemistry, National Taiwan University, Taipei 106, Taiwan, R.O.C.
}

\begin{abstract}
Protein tyrosine phosphatases (PTPases) are an important class of enzymes involved in the regulation of many cellular events. Here we describe the design and synthesis of an activity probe 2 targeting these PTPases. This mechanism-based activity probe adopts a cassette-like design; a phosphate group serves as the recognition bead and a fluorescent diethylaminocoumarin derivative acts as the reporter group. Compound 3 was phosphorylated with diallyl phosphorochloridate and then fluorinated with DAST to give versatile intermediate 5. The Boc protective group of compound 5 was removed by TFA to make available the amino group where a diethylaminocoumarin chromophore was later attached. Final deprotection of the allyl group from the phosphate head gives our complete activity probe 2 . It will be used in the labeling study of PTPases from various sources.
\end{abstract}

\section{INTRODUCTION}

Protein tyrosine phosphorylation and dephosphorylation is a key switching mechanism for regulating the functions of cellular proteins participating in various physiological processes, including signal transduction, cell growth and differentiation. ${ }^{1,2}$ An exquisite balance between tyrosine phosphorylation and dephosphorylation status is finely maintained by the combined action of kinases ${ }^{3}$ and phosphatases $;{ }^{2,4}$ the former are responsible for adding a phosphate group to a tyrosine residue and the latter for the removal of it. Due to their essential roles in the processes, protein tyrosine phosphatases (PTPases) have become an important target for biochemical and pharmaceutical research. ${ }^{4,5,6}$ PTPases are a large family of enzymes that vary to a great extent in their structures and could exist in either nonmembrane cytosolic or receptor-like transmembrane forms. ${ }^{2,7}$ It has been suggested that as many as 500 PTPases might be encoded within the human genome, yet so far only about 75 of them have been identified. ${ }^{4}$ Therefore, it would be of great interest to survey the distribution of PTPases at the protein level.

In our continuing efforts to screen and select biocatalysts with the desired hydrolytic activities, we have developed a mechanism-based approach to achieve this goal. Along the way, activity probes, originating from the concept of suicide substrates, ${ }^{8}$ have to be designed and prepared. These probes are stable compounds and could be activated when the designated bond is cleaved. This activation step could then result in covalent attachment of the residue to the biocatalyst molecule nearby. This approach has been proven effective in the search of catalytic antibodies with $\beta$ galactosidase activity and in the selection of mutant $\beta$-lactamases from a phage displayed system. ${ }^{9.10}$ Previously, an activity probe with a cassette-like design against a phosphotriesterase was reported; ${ }^{11}$ one end of the probe is the recognition head for the specified hydrolytic activity and the other end is the attachment site for a reporter group. Model compound 1 thus prepared was shown to be able to covalently modify a phosphotriesterase. ${ }^{11}$ In this report, we extend this cassette-like design and prepare compound 2 (as its triethylammonium salt), which carries a fluorescent reporter group, as a complete activity probe for PTPases. The structures of both compounds are shown in Fig. 1.

\section{RESULTS AND DISCUSSION}

A complete activity probe consists of three parts; a recognition head followed by a trapping device, a linker and a reporter group. The trapping device in this work is the $p$ hydroxybenzylic fluoride moiety which is a latent quinone methide. Its effectiveness has been verified in our previous
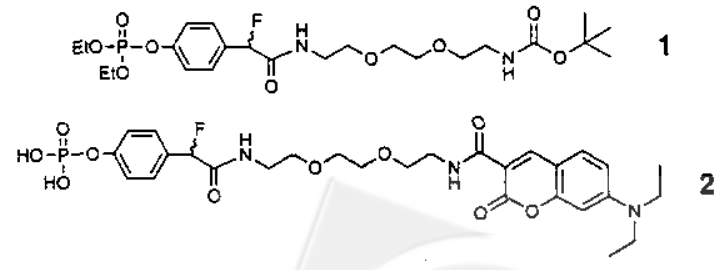

Fig. 1. Structures of activity probes 1 and 2 .

Dedicated to Professor Kung-Tsung Wang on the occasion of his 70th birthday. 
report with the study of compound 1 and a phosphotriesterase. ${ }^{11}$ A phosphate group connecting to the latent quinone methide is located at one end of probe 2 . It plays the role of recognition head and defines the target hydrolytic activity, PTPases. When the phenolic-phosphorus bond of compound 2 is cleaved under the action of PTPases, it would undergo 1,6-elimination to form a reactive quinone methide species. ${ }^{12}$ Here, the $p$-hydroxybenzylic fluoride moiety not only serves as the latent quinone methide trapping device, the phenyl phosphate moiety also mimics a phosphoryl tyrosine residue. The other end of compound 2 is the report group, which is a 7-(diethylamino)coumarin-3-carboxylate derivative in this work. This coumarin derivative is fluorescent ( $\lambda_{\text {ex }}=406 \mathrm{~nm}$ and $\lambda_{\mathrm{em}}=472 \mathrm{~nm}$ ). It can provide extremely high sensitivity when monitored with a fluorescence detector. The head and the report group are connected through an ethylene glycol-like linker to offer better solubility in an aqueous environment.

The synthesis of compound 2 is shown in Scheme $I$. Compound $3,{ }^{11}$ derived from mono-Boc-protected diamine and $p$-hydroxymandelic acid, was used as the starting material in this study. It carries two hydroxyl groups; one is phenolic and the other is secondary. Our previous experience in the synthesis of compound 1 indicates that these two hydroxyl groups display different reactivities. Therefore,

Scheme I

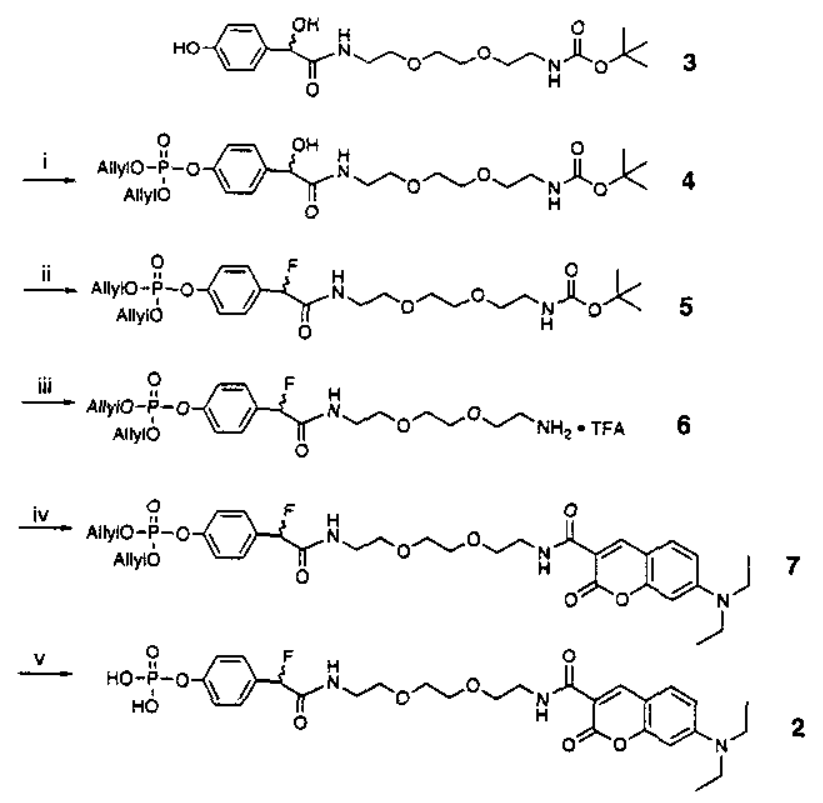

(i) (allylO) 2 POH, $\mathrm{CCl}_{4}, \mathrm{TEA}, \mathrm{DCM}, 91 \%$; (ii) DAST/DCM, 53\%; (iii) TFA/DCM, 100\%; (iv) 7-(diethylamino)courmarin-3-carboxylic acid, EDCI, HOSu, TEA, DCM, 70\%; (v) $\left(\mathrm{Ph}_{3} \mathrm{P}\right)_{4} \mathrm{Pd}$, $n$ $\mathrm{BuNH}_{2}, \mathrm{HCOOH}, \mathrm{THF}, 53 \%$. compound 3 was subjected to phosphorylation without a prior protection step. Several phosphorylation conditions have been attempted, including dialkyl phosphoramidite, ${ }^{13}$ dialkyl phosphorochloridate ${ }^{14}$ and trialkyl phosphite with $\mathrm{I}_{2 .}{ }^{15}$ The phosphorylation step was best accomplished with a modified diallyl phosphorochloridate method. ${ }^{14,16}$ The diallyl phosphorochloridate reagent was generated in situ by adding diallyl phosphite to the mixture of carbon tetrachloride and triethylamine. Under this condition, the phenolic position is preferentially phosphorylated, which is in parallel with the results obtained from reactions using a dibenzyl phosphite reagent ${ }^{16}$ and a diethyl phosphorochloridate reagent as well. ${ }^{11}$ Compound 4 thus obtained $(91 \%$ yield) has the phosphate head temporarily allyl-protected.

The secondary hydroxyl group of compound 4 was then converted to fluoride 5 with diethylaminosulfur trifluoride (DAST) in 53\% yield. The successful fluorination was evidenced by the ${ }^{1} \mathrm{H}$ - and ${ }^{19} \mathrm{~F}-\mathrm{NMR}$ data of compound 5 . The benzylic hydrogen on compound 5 appears as a doublet at $5.73 \mathrm{ppm}$ with a coupling constant of $48.2 \mathrm{~Hz}$, which is characteristic of geminal H-F coupling. Its ${ }^{19} \mathrm{~F}-\mathrm{NMR}$ spectrum also gives a doublet at $\mathbf{- 1 7 8 . 4} \mathrm{ppm}$. Compound $5 \mathrm{not}$ only is a very important intermediate in this synthesis but also carries a critical feature in its design for other activity probes targeting P-O bond cleavage. Since we adopt a cassette-like design, the head group and the reporter group could be changed without having to go through a totally new synthetic route. This core structure has orthogonal protecting groups; therefore, it could be extended from either end, making compound 5 an important and versatile branching point. Unlike compound 1, where an ethyl group was used as the phosphate protecting group and could not be selectively removed, compound 5 uses an ally group as the phosphate protecting group, and therefore, is more flexible.

The target of this study is the protein tyrosine phosphatase activity. We decided to attach a fluorescent reporter group before removing the allyl protective group. Here a coumarin derivative was used as a model chromophore. But we have also included the possibility of tuning the fluorescent properties of the reporter group in this design by replacing them with other suitable fluorescent chromophores. Compound 5 could be selectively and quantitatively deprotected by treatment with trifluoroacetic acid (TFA) in dichloromethane (DCM) to release the amino compound 6 which was then coupled to 7-(diethylamino) coumarin-3carboxylic acid by the action of 1-(3-dimethylaminopropyl)-3-ethylcarbodiimide hydrochloride (EDCl), $\mathrm{N}$-hydroxysuccinimide (HOSu) and triethylamine (TEA) to give allyl-protected product 7 in $70 \%$ yield for two steps. The allyl protective group was finally removed by $n$-butylamine, 
formic acid and triphenylphosphine in the presence of $\left(\mathrm{Ph}_{3} \mathrm{P}\right)_{4} \mathrm{Pd}$ to offer our desired probe $2(53 \%)$, which exists as its triethylammonium salt after purification.

Our ongoing studies include using compound 2 as the activity probe for in vitro labeling of phosphatases and as staining reagent to survey the distribution of phosphatase activity in cells from various sources. We will also construct a new series of activity probes for other $\mathrm{P}-\mathrm{O}$ bond hydrolytic activities from the important intermediate 5 described in this research.

\section{EXPERIMENTAL}

All reagents, solvents and starting materials were obtained from commercial suppliers (Acros, Aldrich and Merck) and used without further purification. IR spectra were taken with Nicolet Magna-IR 550 Series II. ${ }^{1} \mathrm{H}-,{ }^{13} \mathrm{C}$-, ${ }^{19} \mathrm{~F}$ - and ${ }^{31} \mathrm{P}$-NMR spectra were recorded using a Bruker $\mathrm{AC}$ 300 or Bruker Avance 400 spectrometer. Chemical shifts were reported in parts per million $(\delta, \mathrm{ppm})$ using $\mathrm{CDCl}_{3}\left(\delta_{\mathrm{H}}\right.$ 7.24) as internal standard. High resolution mass spectra were recorded with JEOL-102A mass spectrometer. Analytical thin layer chromatography (TLC) was carried out on pre-coated plates (silica gel, 60F-254, Merck) and spots were visualized under UV light and/or phosphomolybdic acid-ethanol. Column chromatography was performed with Kieselgel 60 (70-230 mesh) silica gel (Merck).

\section{Compound 4}

To a solution of starting material $3(512 \mathrm{mg}, 1.28$ $\mathrm{mmol}$ ) in $8 \mathrm{~mL}$ of anhydrous acetonitrile was added $\mathrm{CCl}_{4}$ $(0.63 \mathrm{~mL}, 6.43 \mathrm{mmol})$, TEA $(0.38 \mathrm{~mL}, 2.70 \mathrm{mmol})$ and DMAP (17 mg, $0.13 \mathrm{mmol}$ ). The mixture was stirred and kept cooled with an ice-water bath. One minute later, diallyl phosphite $(305 \mathrm{mg}, 1.86 \mathrm{mmol})$ was added dropwise. The progress of the reaction was monitored by TLC. When the reaction was completed ( $<60 \mathrm{~min}$ ), it was concentrated and the desired product 4 was purified by silica gel column chromatography. The column was eluted with $\mathrm{MeOH} / \mathrm{DCM}$ $(5 / 95 \rightarrow 15 / 85)$ to give $652 \mathrm{mg}$ of compound $4(91 \%)$ as an oil. $R_{f}=0.35\left(\mathrm{MeOH} / \mathrm{CHCl}_{3}=10 / 90\right) .{ }^{1} \mathrm{H}$ NMR $(300 \mathrm{MHz}$, $\left.\mathrm{CDCl}_{3}\right): \delta 1.31(\mathrm{~s}, 9 \mathrm{H}, t-\mathrm{Bu}), 3.16(\mathrm{~m}, 2 \mathrm{H}), 3.32(\mathrm{~m}, 2 \mathrm{H})$, 3.39-3.46 (m, $8 \mathrm{H}), 4.50(\mathrm{~m}, 4 \mathrm{H}$, allylic), $4.83(\mathrm{bs}, 1 \mathrm{H}, \mathrm{NH})$, $5.13-5.28(\mathrm{~m}, 5 \mathrm{H}), 5.80(\mathrm{~m}, 2 \mathrm{H}$, vinylic), $7.03(\mathrm{~d}, J=8.4 \mathrm{~Hz}$, $2 \mathrm{H}$, aromatic), 7.25 (bs, $1 \mathrm{H}, \mathrm{NH}), 7.30(\mathrm{~d}, J=8.4 \mathrm{~Hz}, 2 \mathrm{H}$, aromatic). ${ }^{13} \mathrm{C}$ NMR (75 MHz, $\left.\mathrm{CDCl}_{3}\right): \delta 28.1,38.6,40.0$, $50.0,68.6,69.3,69.8,69.9,73.0,79.0,118.5,120.0$, $127.9,131.7,137.1,149.9,155.9,172.2$. IR (KBr): 3348 , $2982,2938,2880,1704,1170,1101,1040,868 \mathrm{~cm}^{-1}$.
HRMS (FAB): $[\mathrm{M}+\mathrm{H}]^{+} 559.2414$ (calcd 559.2421 for $\left.\mathrm{C}_{25} \mathrm{H}_{40} \mathrm{~N}_{2} \mathrm{O}_{10} \mathrm{P}\right)$.

\section{Compound 5}

To a solution of compound $4(3.58 \mathrm{~g}, 6.4 \mathrm{mmol})$ in 30 $\mathrm{mL}$ of anhydrous dichloromethane was added DAST (3.6 $\mathrm{mL}$ ) in a dropwise manner at $0^{\circ} \mathrm{C}$. When no more starting material was observed by TLC monitoring, the reaction was quenched by slowly adding $\mathrm{MeOH}$ at $0^{\circ} \mathrm{C}$. The mixture was stirred for $30 \mathrm{~min}$, then concentrated and followed by silica gel column chromatography. It was eluted with $\mathrm{MeOH} / \mathrm{DCM}(6 / 94 \rightarrow 8 / 92)$ to give $1.90 \mathrm{~g}$ of fluorinated product $5(53 \%)$ as an oil. $R_{f}=0.52\left(\mathrm{MeOH} / \mathrm{CHCl}_{3}=\right.$ 10/90). ${ }^{1} \mathrm{H}$ NMR $\left(300 \mathrm{MHz}, \mathrm{CDCl}_{3}\right): \delta 1.40(\mathrm{~s}, 9 \mathrm{H}, t-\mathrm{Bu})$, $3.29(\mathrm{~m}, 2 \mathrm{H}), 3.49-3.60(\mathrm{~m}, 10 \mathrm{H}), 4.59(\mathrm{~m}, 4 \mathrm{H}$, allylic), 5.00 (bs, $1 \mathrm{H}, \mathrm{NH}), 5.20-5.35(\mathrm{~m}, 4 \mathrm{H}), 5.73(\mathrm{~d}, J=48.2 \mathrm{~Hz}, 1 \mathrm{H}$, CHF), $5.91(\mathrm{~m}, 2 \mathrm{H}$, vinylic), $7.00(\mathrm{bs}, 1 \mathrm{H}, \mathrm{NH}), 7.21(\mathrm{~d}, J=$ $8.3 \mathrm{~Hz}, 2 \mathrm{H}$, aromatic), 7.42 (d, $J=8.3 \mathrm{~Hz}, 2 \mathrm{H}$, aromatic). ${ }^{13} \mathrm{C}$ NMR $\left(75 \mathrm{MHz}, \mathrm{CDCl}_{3}\right): \delta 28.2,38.8,40.2,50.2,68.7$, 69.4, 70.0, 70.1, 73.1, 89.8, 92.3, 118.6, 119.8, 128.0, $131.8,137.0,150.1,156.5,172.3 .{ }^{19} \mathrm{~F}$ NMR $(300 \mathrm{MHz}$, $\left.\mathrm{CDCl}_{3}\right): \delta-178.4(\mathrm{~d}, J=50.4 \mathrm{~Hz}) .{ }^{31} \mathrm{P}$ NMR $(300 \mathrm{MHz}$, $\left.\mathrm{CDCl}_{3}\right): \delta-5.89$. IR (KBr): 3333, 2927, 2879, 1689, $1511,1458,1368,1280,1110,1019,947,844 \mathrm{~cm}^{-1}$. HRMS (FAB): $[\mathrm{M}+\mathrm{H}]^{+} 561.2383$ (calcd 561.2377 for $\left.\mathrm{C}_{20} \mathrm{H}_{31} \mathrm{FN}_{2} \mathrm{O}_{7} \mathrm{P}\right)$.

\section{Compound 7}

The fluorinated compound $5(448 \mathrm{mg}, 0.80 \mathrm{mmol})$ was dissolved in $3 \mathrm{~mL}$ of dichloromethane. A solution of $75 \%$ TFA in DCM $(6 \mathrm{~mL})$ was then added to the above mixture with the cooling of an ice bath. Upon completion of the addition, the ice bath was removed and the reaction mixture was allowed to warm to room temperature. When no more compound 5 was observed $(\sim \mathrm{hr})$, the reaction mixture was concentrated to dryness to give crude deprotected product 6 as its TFA salt $(100 \%)$. It was used for the next coupling step without further purification. ' $\mathrm{H}$ NMR $(300 \mathrm{MHz}$, $\left.\mathrm{CDCl}_{3}\right): \delta 2.94(\mathrm{~m}, 2 \mathrm{H}), 3.25-3.52(\mathrm{~m}, 10 \mathrm{H}), 4.59(\mathrm{~m}, 4 \mathrm{H}$, allylic), 5.18-5.33 (m, $4 \mathrm{H}$, vinylic), $5.71(\mathrm{~d}, J=47.8 \mathrm{~Hz}, 1 \mathrm{H}$, CHF), 5.87 (m, $2 \mathrm{H}$, vinylic), 7.15 (d, $J=8.2 \mathrm{~Hz}, 2 \mathrm{H}$, aromatic), 7.41 (d, $J=8.2 \mathrm{~Hz}, 2 \mathrm{H}$, aromatic). ${ }^{19} \mathrm{~F}$ NMR (300 $\left.\mathrm{MHz} \mathrm{CDCl}_{3}\right): \delta-178.4(\mathrm{~d}, J=50.4 \mathrm{~Hz}) .{ }^{31} \mathrm{P}$ NMR $(300$ $\mathrm{MHz}, \mathrm{CDCl}_{3}$ ); $\delta-1.41$. HRMS (FAB): $[\mathrm{M}+\mathrm{H}]^{+} 461.1835$ (calcd 461.1853 for $\mathrm{C}_{25} \mathrm{H}_{39} \mathrm{FN}_{2} \mathrm{O}_{9} \mathrm{P}$ ).

To a cooled solution of 7-(diethylamino)coumarin-3carboxylic acid ( $258 \mathrm{mg}, 1.04 \mathrm{mmol}$ ) and $N$-hydroxysuccinimide (120 mg, $1.04 \mathrm{mmol}$ ) in $5 \mathrm{~mL}$ of anhydrous acetonitrile was added $200 \mathrm{mg}$ of EDCI ( $1.04 \mathrm{mmol}$ ). The reaction was stirred and kept cooled for $2 \mathrm{~h}$. A solution of compound 
$6(0.80 \mathrm{mmol})$ from the previous stage and TEA $(0.22 \mathrm{~mL}$, $1.61 \mathrm{mmol}$ ) in $3 \mathrm{~mL}$ of anhydrous acetonitrile was then prepared and slowly added to the reaction mixture through a syringe. The reaction was allowed to warm to room temperature and stirred overnight. It was then quenched by adding $100 \mu \mathrm{L}$ of water and concentrated to dryness. The coupling product 7 ( $394 \mathrm{mg}, 70 \%$ ) was purified by silica gel column chromatography eluted with MeOH/DCM $(8 / 92 \rightarrow$ 16/84). $R_{f}=0.55\left(\mathrm{MeOH} / \mathrm{CHCl}_{3}=10 / 90\right) .{ }^{1} \mathrm{H}$ NMR $(400$ $\left.\mathrm{MHz}, \mathrm{CDCl}_{3}\right): \delta 1.18(\mathrm{t}, J=7.0 \mathrm{~Hz}, 6 \mathrm{H}), 3.40(\mathrm{q}, J=7.0 \mathrm{~Hz}$, $4 \mathrm{H}), 3.48-3.68(\mathrm{~m}, 12 \mathrm{H}), 4.58(\mathrm{~m}, 4 \mathrm{H}$, allylic), $5.15(\mathrm{~m}, 4 \mathrm{H}$, vinylic), $5.72(\mathrm{~d}, J=48.2 \mathrm{~Hz}, 1 \mathrm{H}, \mathrm{CHF}), 5.79-5.95(\mathrm{~m}, 2 \mathrm{H}$, vinylic), $6.42(\mathrm{~s}, 1 \mathrm{H}), 6.60(\mathrm{~d}, J=9.0 \mathrm{~Hz}, 1 \mathrm{H}), 7.18(\mathrm{~d}, J=$ $8.4 \mathrm{~Hz}, 2 \mathrm{H}$, aromatic), $7.28(\mathrm{bs}, 1 \mathrm{H}), 7.34-7.46(\mathrm{~m}, 3 \mathrm{H})$, $8.64(\mathrm{~s}, 1 \mathrm{H}), 9.02(\mathrm{bs}, 1 \mathrm{H}) .{ }^{13} \mathrm{C} \mathrm{NMR}\left(100 \mathrm{MHz}, \mathrm{CDCl}_{3}\right): \delta$ $12.3,39.0,39.3,45.0,68.8,69.5,69.7,70.3,70.4,89.7$, $92.2,96.4,108.3,109.9,110.2,118.7,120.0,128.2,131.0$, $131.9,148.0,151.1,152.5,157.5,162.6,163.1,168.1$, 168.4. ${ }^{19} \mathrm{~F}$ NMR $\left(400 \mathrm{MHz}, \mathrm{CDCl}_{3}\right): \delta-178.4(\mathrm{~d}, J=51.2$ Hz). ${ }^{31} \mathrm{P}$ NMR (400 MHz, $\mathrm{CDCl}_{3}$ ): $\delta$ - 1.41. HRMS (FAB): $[\mathrm{M}+\mathrm{H}]^{+} 704.2745$ (calcd 704.2702 for $\mathrm{C}_{34} \mathrm{H}_{44} \mathrm{FN}_{3} \mathrm{O}_{10} \mathrm{P}$ ).

\section{Compound 2}

To a mix ture of compound 7 ( $95.5 \mathrm{mg}, 0.136 \mathrm{mmol})$ and $\mathrm{PPh}_{3}(21.4 \mathrm{mg}, 0.081 \mathrm{mmol})$ was added THF $(5 \mathrm{~mL}), n$ butylamine ( $1 \mathrm{~mL})$ and formic acid $(4 \mathrm{~mL})$. It was then followed by the addition of $15.7 \mathrm{mg}$ of $\left(\mathrm{PPh}_{3}\right)_{4} \mathrm{Pd}(0.014$ $\mathrm{mmol}$ ). The reaction was stirred at room temperature for 2 $h$, after which time no more starting material was observed by TLC. It was concentrated to a syrup, then diluted with 10 $\mathrm{mL}$ of $\mathrm{H}_{2} \mathrm{O}$ and $200 \mu \mathrm{L}$ of TEA. The aqueous phase was extracted three times with $8 \mathrm{~mL}$ of ether, followed by concentration to dryness. The target product 2 was purified by silica gel column chromatography eluted with $\mathrm{CHCl}_{3} / \mathrm{MeOH} /$ $\mathrm{TEA}=85 / 15 / 5$. It was further desalted with a short $\mathrm{C}_{18}$ cartridge to give compound 2 as its triethylammonium salt (59.4 mg, 53\%). $R_{f}=0.52\left(\mathrm{MeOH} / \mathrm{CHCl}_{3} / \mathrm{HOAc}=\right.$ 25/75/5). ${ }^{1} \mathrm{H}$ NMR $\left(400 \mathrm{MHz}, \mathrm{CDCl}_{3}\right): \delta 1.05-1.20(\mathrm{~m}$, $24 \mathrm{H}), 2.74(\mathrm{q}, J=7.3 \mathrm{~Hz}, 12 \mathrm{H}), 3.37(\mathrm{q}, J=7.0 \mathrm{~Hz}, 4 \mathrm{H})$, 3.53-3.62 (m, 12H), 5.60 (d, $J=48.4 \mathrm{~Hz}, 1 \mathrm{H}, \mathrm{CHF}), 6.36$ (d, $J=2.1 \mathrm{~Hz}, 1 \mathrm{H}), 6.55(\mathrm{dd}, J=9.0,2.1 \mathrm{~Hz}, 1 \mathrm{H}), 7.19(\mathrm{bs}, 4 \mathrm{H})$, $7.33(\mathrm{~d}, J=9.0 \mathrm{~Hz}, 1 \mathrm{H}), 7.45(\mathrm{bs}, 1 \mathrm{H}), 8.56(\mathrm{~s}, 1 \mathrm{H}), 8.94$ (bs, 1H). ${ }^{13} \mathrm{C} \mathrm{NMR}\left(100 \mathrm{MHz}, \mathrm{CDCl}_{3}\right): \delta 7.7,12.2,38.8,39.1$, $44.9,45.4,69.3,69.5,70.0,70.2,90.3,92.2,96.2,108.0$, $109.7,109.8,120.3,128.3,130.9,147.8,152.4,154.8$, $157.4,162.5,163.0,168.5,168.7 .{ }^{19} \mathrm{~F}$ NMR $(400 \mathrm{MHz}$, $\left.\mathrm{CDCl}_{3}\right): \delta-172.6(\mathrm{~d}, J=52.0 \mathrm{~Hz}) .{ }^{31} \mathrm{P} \mathrm{NMR}(400 \mathrm{MHz}$, $\mathrm{CDCl}_{3}$ ): $\delta-3.29$. HRMS (FAB): $[\mathrm{M}+\mathrm{H}]^{+} 624.2083$ (calcd 624.2122 for $\left.\mathrm{C}_{28} \mathrm{H}_{36} \mathrm{FN}_{3} \mathrm{O}_{10} \mathrm{P}\right)$.

\section{ACKNOWLEDGEMENTS}

This work was supported by the National Science Council (NSC 88-2113-M-002-022).

Received June 3, 1999.

\section{Key Words}

Activity probe; Biocatalyst; Coumarin; Fluorescent; Mechanism-based selection; Protein tyrosine phosphatase; Quinone methide.

\section{REFERENCES}

1. Tonks, N. K.; Neel, B. G. Cell 1996, 87, 365-368.

2. Walton, K. M.; Dixon, J. E. Annu. Rev. Biochem. 1993, $62,101-120$.

3. Fantl, W. J.; Johnson, D. E.; William, L. T. Annu. Rev. Biochem. 1993, 62, 453-481.

4. Barford, D.; Jia, Z.; Tonks, N. K. Nat. Struct. Biol. 1995 , 2, 1043-1053.

5. Guan, K. L.; Dixon, J. E. Science 1990, 249, 553-556.

6. Guan, K. L.; Broyles, S. S.; Dixon, J. E. Nature 1991, 350, 359-362.

7. Fischer, E. H.; Charbonnear, H.; Tonks, N. K. Science 1991, 253, 401-406.

8. Silverman, R. B. "Mechanism-Based Enzyme Inactivation: Chemistry and Enzymology", 1988, CRC Press, Boca Raton, Florida.

9. Janda, K. D.; Lo, L.-C.; Lo, C.-H. L.; Sim, M.-M.; Wang, R.; Wong, C.-H.; Lemer, R. A. Science 1997, 275, 945 948.

10. Soumillion, P.; Jespers, L.; Bouchet, M.; Marchand-Brynaert, J.; Winter, G.; Fastrez, J. J. Mol. Biol. 1994, 237 , 415-422.

11.Lo, L.-C.; Lo, C.-H. L.; Janda, K. D. Bioorg. Med. Chem. Lett. 1996, 6, 2117-2120.

12. Wakselman, M. Nouv. J. Chim. 1983, 7, 439-447.

13. Bannwarth, W.; Küng, E. Tetrahedron Lett. 1989, 30, 4219-4222.

14. Hayakawa, Y.; Wakabayashi, S.; Nobori, T.; Noyori, R. Tetrahedron Lett. 1987, 28, 2259-2262.

15. Stowell, J. K.; Widlanski, T. S. Tetrahedron Lett. 1995 , $36,1825-1826$.

16. Silverberg, L. J.; Dillon, J. L.; Vermishetti, P. Tetrahedron Lett. 1996, 37, 771-774. 